\title{
Can Serum B12 Level Be Used As An Effective Differential Criterion in Differential Diagnosis of Primary and Secondary Polycythemia?
}

\author{
Serum B12 Düzeyi Primer ve Sekonder Polisitemi Ayrıcı \\ Tanısında Etkin Bir Ayrıcı Tanı Kriteri Olarak Kullanılabilir \\ mi?
}

Sinan Demircioglu ${ }^{1}$,

Serkan Budancamanak ${ }^{2}$, Ali Dogan ${ }^{1}$

'Van Yüzüncü Yıl University, Faculty of Medicine, Department of Hematology, Van, Turkey

${ }^{2}$ Van Yüzüncü Yıl University, Faculty of Medicine, Department of Internal Medicine, Van, Turkey

Geliş Tarihi/Received: 22 May 2019 Kabul Tarihi/Accepted: 19 July 2019

Address correspondence to: Sinan Demircioglu, Van Yüzüncü YII University, Faculty of Medicine, Department Hematology, Van, Turkey

e-mail: sinandemircioglumd@gmail.com

\section{ORCID}

Sinan Demircioglu

https://orcid.org/0000-0003-1277-5105

Serkan Budancamanak

https://orcid.org/0000-0002-2591-6168

Ali Dogan

https://orcid.org/0000-0003-0207-3505

\begin{abstract}
Öz
Amaç: Polisitemia vera'da (PV) JAK2 V617F mutasyonu \%95 oranında saptanmaktadır. Fakat bu test hem yüksek maliyetli hem de zaman alan bir tetkiktir. Bu çalışmada sekonder polisitemiyi (SP) dışlayabilmek için JAK2 V617F mutasyonuna ilave olarak kullanılabilecek hızlı, ucuz ve kolay ulaşılabilen bir tetkik araştırılması planlanmıştır.

Hastalar ve Yöntem: Bu çalıșmaya Dünya Sağlık Örgütünün 2016 tanı kriterlerine göre tanı almış 39 PV hastası ve $51 \mathrm{SP}$ hastası alındı. Hastaların demografik özellikleri, fizik muayene bulguları ve laboratuvar sonuçları tespit edildi. Bu iki grup arasında istatiksel analiz yapıldı.

Bulgular: PV grubunda, serum B12 düzeyi, eritrosit sayısı, lökosit sayısı, nötrofil sayısı, trombosit sayıs ve laktat dehidrogenaz düzeyi SP grubundan istatiksel olarak anlamlı derecede yüksek bulunmuştur Serum B12 düzeyinin $343 \mathrm{pg} / \mathrm{mL}$ 'nin üzerinde olması PV-SP ayrımı için eşik değer olarak saptanmıştır.

Sonuç: Yüksek serum B12 düzeyi PV ile ilişkili bulunmuştur. Fakat serum B12 düzeyinin primer ve sekonder polisitemi ayrıcı tanısında kullanılabilmesi için bu çalışmada ki verileri destekleyen daha geniş
\end{abstract} hasta serileri ile yapılan prospektif çalışmalara ihtiyaç vardır.

Anahtar Kelimeler: Polisitemi, primer, sekonder, vitamin B12, eritrosit

\begin{abstract}
Aim: JAK2 V617F mutation is determined in $95 \%$ of polycythemia vera (PV) patients. However, this test is a high-cost and time-consuming examination. In this study, a rapid, inexpensive and easily available test that can be used in addition to JAK2 V617F mutation is planned to exclude secondary polycythemia (SP). Patients and Methods: A total of 39 PV patients and 51 SP patients, who were diagnosed according to 2016 diagnostic criteria of World Health Organization, have been included in this study. Demographics physical examination findings and laboratory results of patients have been determined. A statistical analysis was performed between these two groups.

Results: In PV group, serum vitamin B12 level, erythrocyte count, leukocyte count, neutrophil count, platelet count and lactate dehydrogenase levels were determined to be statistically significantly highe than SP group. Serum vitamin B12 level above $343 \mathrm{pg} / \mathrm{mL}$ has been determined as the threshold value for the differentiation of PV from SP.

Conclusion: High serum vitamin B12 level was determined to be associated with PV. However, there is a need for prospective studies performed with larger patient series supporting the data obtained in this study in order for serum vitamin B12 level to be used in the differential diagnosis of primary and secondary polycythemia.
\end{abstract}

Abstract

Key words: Polycythemia, primary, secondary, vitamin B12, erythrocyte

\section{INTRODUCTION}

Polycythemia means to the increase in erythrocyte mass. Hemoglobin $(\mathrm{Hb})$ levels above $>16.5 \mathrm{~g} / \mathrm{dL}$ in men and $>16.0 \mathrm{~g} / \mathrm{dL}$ in women, and hematocrit (Hct) levels above $>49 \%$ in men and $>48 \%$ in women have been defined as polycythemia (1). Absolute polycythemia is examined under two topics which are primary and secondary polycythemia. While primary polycythemia is developed due to a mutation in erythrocyte precursors, secondary polycythemia (SP) is developed due to increased erythropoietin (EPO) level (2). While EPO increases are often observed due to hypoxemia, they may also be presented due to renal transplant, EPO-producing tumors, renal artery stenosis and hydronephrosis (3-6). JAK2 V617F mutation is observed in about $95 \%$ of polycythemia vera (PV) patients (7). This mutation is used as a major criterion in the diagnosis of PV (1). Increased EPO and absence of JAK2 V617F mutation should suggest SP in cases with polycythemia. The patients
Cite this article as: Demircioglu S, Budancamanak S, Dogan A. Can Serum B12 Level Be Used As An Effective Differential Criterion in Differential Diagnosis of Primary and Secondary Polycythemia? Selcuk Med J 2020;36(1): 22-26
Disclosure: None of the authors has a financial interest in any of the
products, devices, or drugs mentioned in this article. The research was
not sponsored by an outside organization. All authors have agreed to allow
full access to the primary data and to allow the journal to review the data
if requested. 
who were considered to have SP should be evaluated with regard to smoking, the altitude of their residence, pulmonary and cardiac diseases that could cause hypoxia (8). The rate of normal oxygen saturation, and normal pulmonary and cardiac evaluation are observed in SP due to high altitude. Different from other secondary polycythemias, these findings complicate the differentiation of high altitude SP from PV.

The purpose of this study is to evaluate serum vitamin B12 level in primary and secondary polycythemia patients at the time of diagnosis.

\section{PATIENTS AND METHODS}

A total of 90 patients, consisting of 39 patients diagnosed with $\mathrm{PV}$ and 51 patients diagnosed with SP, who were followed in Hematology Clinic between years 2010-2018, has been included in this retrospective study. Hemoglobin $(\mathrm{Hb})$ levels of $>16 \mathrm{~g} / \mathrm{dl}$ in women and $\mathrm{Hb}>16,5 \mathrm{~g} / \mathrm{dl}$ in men were acknowledged as polycythemia. Criteria determined by World Health Organization on 2016 were used as PV diagnosis criteria. Patients for whom PV diagnosis was excluded were recognized to have SP. Demographic data, physical examination findings, serum vitamin B12 levels, complete blood count results, JAK2 V617F mutation status, EPO levels and oxygen saturation of patients have been determined at the time of diagnosis. Serum vitamin B12 levels at $>300 \mathrm{pg} / \mathrm{ml}$ were considered normal, between 200$300 \mathrm{pg} / \mathrm{ml}$ were considered borderline, and <200 pg/ $\mathrm{ml}$ were considered to be low.

While our study expresses the continuous variables with their descriptive characteristics as mean, standard deviation, minimum and maximum values, the categorical variables are expressed in terms of frequencies and percentages. While analyzing the data, Kolmogorov-Smirnov normality test was used to determine the suitability of the continuous variables for normal distribution. The data that were normally distributed were analyzed by using independentsamples t-test, while the non-normally distributed data were analyzed by using Mann-Whitney $U$ test. The threshold values of B12 were determined by ROC curve analysis. A p value of $<0.05$ was accepted to be statistically significant. The analyses were carried out using SPSS 24. Approval was received from the Noninvasive Clinical Research Ethics Board at Van Yüzüncü Yıl University with the date 23.11.2018 and approval number 09.

\section{RESULTS}

A total of 90 patients, consisting of $39 \mathrm{PV}$ and 51 SP patients, have been included in this study. Mean age was 55.49 \pm 11.18 in PV group, 22 (56.4\%) of these patients were male and $17(43.6 \%)$ were female. In SP group, mean age was $38.14 \pm 13.52$, and $48(94.1 \%)$ of patients were male and $3(5.9 \%)$ were female. $30.8 \%$ of patients in PV group was determined to have splenomegaly and $23.1 \%$ was determined to have hepatomegaly. While no splenomegaly was determined in SP group, hepatomegaly was determined in $3.9 \%$ of the patients in this group. Patient characteristics are presented in Table 1 (Table 1). SP reasons were determined as smoking $(66.7 \%)$, high altitude $(27.4 \%)$ and chronic obstructive pulmonary disease (5.9\%).

Mean $\mathrm{Hb}$, mean corpuscular volume (MCV), mean corpuscular hemoglobin $(\mathrm{MCH})$, mean corpuscular hemoglobin concentration $(\mathrm{MCHC})$ and EPO levels were determined to be statistically significantly lower in PV group compared to SP group $(p<0.05)$. Red blood cell (RBC), red cell distribution width (RDW), white blood cell (WBC), neutrophil count, platelet count and lactate dehydrogenase (LDH) were determined to be higher in PV group compared to SP group $(p<0.05)$. Lymphocyte count, mean platelet volume (MPV), folic acid, indirect bilirubin and oxygen saturation levels were determined to be similar in both groups $(p>0.05)$.

Table 1. Patient characteristics

\begin{tabular}{|c|c|c|}
\hline & PV (\%) & SP (\%) \\
\hline$\overline{\text { Age }}$ & $55.49 \pm 11.18$ & $38.14 \pm 13.52$ \\
\hline Male & $22(56.4)$ & $48(94.1)$ \\
\hline Female & $17(43.6)$ & $3(5.9)$ \\
\hline \multicolumn{3}{|l|}{ Smoking } \\
\hline Yes & $16(41)$ & $34(66.7)$ \\
\hline No & $23(59)$ & $17(33.3)$ \\
\hline \multicolumn{3}{|c|}{ Splenomegaly } \\
\hline Yes & $12(30.8)$ & $0(0)$ \\
\hline None & $27(69.2)$ & $51(100)$ \\
\hline \multicolumn{3}{|c|}{ Hepatomegaly } \\
\hline Yes & $9(23.1)$ & $2(3.9)$ \\
\hline None & $30(76.9)$ & $49(96.1)$ \\
\hline \multicolumn{3}{|l|}{ Thrombosis } \\
\hline Yes & $10(25.6)$ & $2(3.9)$ \\
\hline None & $29(74.4)$ & $49(96.1)$ \\
\hline \multicolumn{3}{|c|}{ Erythromelalgia } \\
\hline Yes & $21(53.8)$ & $27(52.9)$ \\
\hline None & $18(46.2)$ & $24(47.1)$ \\
\hline \multicolumn{3}{|l|}{ JAK2 V617F } \\
\hline Positive & $34(87.2)$ & $0(0)$ \\
\hline Negative & $5(12.8)$ & $51(100)$ \\
\hline
\end{tabular}


The relation between PV and SP groups with regard to laboratory parameters is demonstrated in Table 2 (Table 2).

Mean B12 level was 463 $\pm 269(\mathrm{pg} / \mathrm{mL})$ in PV group while it was found as $307 \pm 147(\mathrm{pg} / \mathrm{mL})$ in SP group. This difference was determined to be statistically significant ( $p: 0.002)$. While serum vitamin B12 level was determined as $>300 \mathrm{pg} / \mathrm{mL}$ in $70 \%$ of PV patients, it was determined above $>300 \mathrm{pg} / \mathrm{ml}$ in $30 \%$ of SP patients. The ROC analysis of the curve (AUC) of 0.697 (Figure 1). A cut-off value of $343 \mathrm{pg} / \mathrm{mL}$ for B12 was able to estimate primary and secondary PV separation with $64 \%$ and $75 \%$, respectively (likelihood ratio-LR $=2.54$ ).

Table 2. The relation between PV and SP according to laboratory values

\begin{tabular}{|c|c|c|c|}
\hline & PV (Mean $\pm S D)$ & SP (MeantSD) & P value \\
\hline Hemoglobin (g/dl) & $18.14 \pm 1.35$ & $18.39 \pm 0.86$ & 0.016 \\
\hline $\operatorname{MCV}(\mathrm{fL})$ & $83.18 \pm 12.03$ & $90.04 \pm 3.54$ & 0.000 \\
\hline $\mathrm{MCH}(\mathrm{pg})$ & $26.28 \pm 4.92$ & $29.55 \pm 1.44$ & 0.000 \\
\hline $\mathrm{MCHC}(\mathrm{g} / \mathrm{dL})$ & $31.36 \pm 1.66$ & $32.65 \pm 0.95$ & 0.004 \\
\hline RBC (million $/ \mu L)$ & $6.93 \pm 1.34$ & $6.12 \pm 0.37$ & 0.000 \\
\hline RDW-SD (fL) & $59.25 \pm 7.07$ & $55.45 \pm 3.63$ & 0.006 \\
\hline WBC $(/ \mu L)$ & $11,246 \pm 3499$ & $7,931 \pm 1677$ & 0.000 \\
\hline Neutrophil count $(/ \mu \mathrm{L})$ & $8,092 \pm 3,449$ & $4,405 \pm 1420$ & 0.000 \\
\hline Lymphocyte count $(/ \mu \mathrm{L})$ & $2,141 \pm 813$ & $2,630 \pm 715$ & 0.230 \\
\hline Platelet count $(/ \mu \mathrm{L})$ & $455,256 \pm 236,157$ & $233,333 \pm 51,676$ & 0.000 \\
\hline MPV (fL) & $8.74 \pm 0.89$ & $8.75 \pm 0.74$ & 0.129 \\
\hline $\mathrm{B} 12(\mathrm{pg} / \mathrm{mL})$ & $463 \pm 269$ & $307 \pm 147$ & 0.002 \\
\hline Folic acid (ng/mL) & $6.34 \pm 3.56$ & $6.09 \pm 2.35$ & 0.073 \\
\hline LDH (U/L) & $361 \pm 140$ & $206 \pm 66$ & 0.000 \\
\hline Indirect bilirubin (mg/dL) & $0.56 \pm 0.28$ & $0.73 \pm 1.26$ & 0.283 \\
\hline Erythropoietin (mU/mL) & $3.93 \pm 4.03$ & $10.42 \pm 8.19$ & 0.004 \\
\hline Oxygen saturation (\%) & $94.31 \pm 2.31$ & $94.45 \pm 3.04$ & 0.562 \\
\hline
\end{tabular}

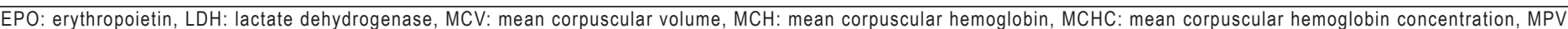
mean platelet volume, RBC: red blood cell, RDW: red cell distribution width, WBC: white blood cell

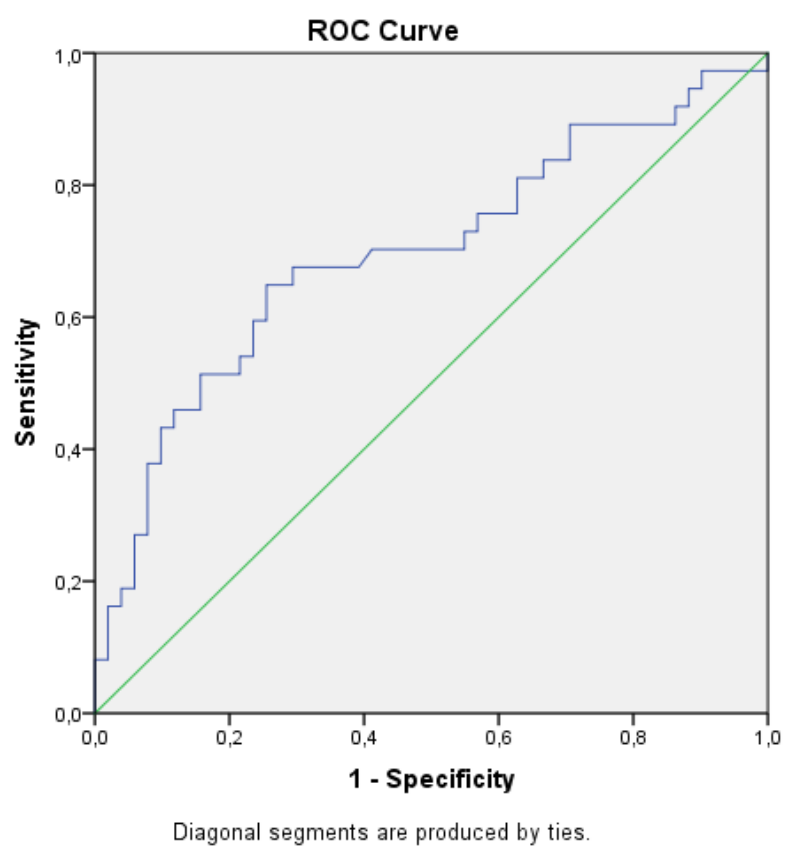

Figure 1. ROC analysis for B12

\section{DISCUSSION}

Vitamin B12 is a water soluble vitamin present in lipid, carbohydrate and protein metabolism. This vitamin is particularly important for normal growth and development, bone marrow function and nervous system function. The reasons of vitamin B12 deficiency, clinical manifestations induced by its deficiency, and its treatment have been described extensively (9). Total serum vitamin B12, including both bound and free forms, are measured in Vitamin B12 analyses. Most of Vitamin B12 (70\% - 90\%) is bound to haptocorrin $(\mathrm{HC})$, and its metabolically active form (10\%-30\%) is bound to transcobalamin (10). Increased Vitamin B12 levels is a result of one or several of the following mechanisms: It may be explained with increased plasma level of transcobalamin I / III produced by myeloid, hepatic and other cell types, increased hepatic cytolysis, decreased vitamin B12 clearance by the liver, decreased transcobalamin II production by the liver and thus decreased transfer into peripheral tissues, increased gastrointestinal 
intake or therapeutic applications (11). Circulating cobalamin-binding proteins and antibodies that cause high plasma cobalamin levels have also been reported (12).

High serum vitamin B12 levels are not associated with symptoms or toxicity, but while some can be associated with some conditions that are completely benign (e.g., parenteral vitamin B12 injection, use of vitamin B12 preparations), others may be a sign of serious diseases. When an underlying malignant disease is determined to be the reason of high vitamin B12 level, malignancy is generally at a stage not determined before and/or at a non-metastatic stage (11). High serum levels of vitamin B12 have been shown to be associated with diseases such as renal failure, cancer, hematologic malignancy (e.g. acute or chronic leukemia), myeloproliferative disorders (polycythemia vera, essential thrombocytosis, chronic myeloid leukemia, primary myelofibrosis), hypereosinophilic syndrome and hepatic disease (e.g. cirrhosis, hepatitis, hepatocellular carcinoma and metastatic liver tumors) $(13,14)$.

It has been reported that serum vitamin B12 levels are determined to be high in $30 \%-50 \%$ of polycythemia vera patients $(15,16)$. In our study, serum vitamin B12 level was determined to be above $>300 \mathrm{pg} / \mathrm{mL}$ in $70 \%$ of $\mathrm{PV}$ patients. While these increases are less dramatic compared to chronic myeloid leukemia, high plasma concentration of cobalamin is also due to increased HC. Increased vitamin B12 levels $(>900 \mathrm{ng} / \mathrm{ml})$ or increased unsaturated vitamin B12 binding capacity $(>2200 \mathrm{ng} / \mathrm{ml})$ were indicated in PV diagnostic criteria described by Polycythemia Vera Study Group on 1975 (17). High vitamin B12 level is not among the new diagnostic criteria of today (1). In our study, vitamin B12 was determined to be higher in PV group. There are no other studies comparing B12 levels in PV and SP in the literature. This is the first study showing that B12 is higher in PV patients compared to SP patients. Vitamin B12 threshold level that could be used in the differentiation of two groups was determined as $>343 \mathrm{pg} / \mathrm{mL}$. Furthermore, leukocyte count, neutrophil count and platelet count was determined to be high in PV patients, as it was expected from PV.

Smoking causes tissue hypoxia by mechanisms such as increased carboxyhemoglobin in the blood, causing lung disease, and increased erythrocyte oxidant damage in the pulmonary circulation (18). These will lead to erythrocytosis as a result of inadequate oxygenation of blood circulation through the lungs and consequent increased production of erythropoietin (19). We found that cigarette smoking and high altitude play a role in the etiology of $94.1 \%$ of the SP. Oxygen saturation was determined to be similar in PV and SP groups. The geographic area of our study has a high altitude. High altitude polycythemia patients often apply to our clinic. JAK2 V617F mutation is checked in patients with normal oxygen saturation and no cardiopulmonary diseases. While this test is not easily accessible, it is also an expensive and time-consuming method. For this reason, new approaches are needed to differentiate high altitude polycythemia patients. Serum vitamin B12 levels may be an additional test to help JAK2 V617F mutation in the diagnosis of polycythemia. According to the results of our study, high vitamin B12 levels, leukocytosis, neutrophilia and thrombocytosis have supporting attributions for PV.

The limitations of our study are the low number of patients, that it is a retrospective study, the fact that mean age was not similar between two groups, and different gender distribution in these groups.

In conclusion, serum vitamin B12 levels were determined to be higher in PV patients compared to SP patients. There is a need for prospective studies performed with a larger number of patients on this subject in order for serum vitamin B12 level to be used as one of the criteria for differential diagnosis of PV and SP.

Conflict of interest: Authors declare that there is no conflict of interest between the authors of the article.

Financial conflict of interest: Authors declare that they did not receive any financial support in this study.

Address correspondence to: Sinan Demircioglu, Van Yüzüncü Yıl University, Faculty of Medicine, Department of Hematology, Van, Turkey

Phone: 05554324474

e-mail: sinandemircioglumd@gmail.com

\section{REFERENCES}

1. Arber DA, Orazi A, Hasserjian R, et al. The 2016 revision to the world health organization classification of myeloid neoplasms and acute leukemia. Blood 2016;127(20):2391405.

2. McMullin MF, Bareford D, Campbell P, et al. Guidelines for the diagnosis, investigation and management of polycythaemia/ erythrocytosis. Br J Haematol 2005;130(2):174-95.

3. Kew MC, Fisher JW. Serum erythropoietin concentrations in patients with hepatocellular carcinoma. Cancer 1986;58(11):2485-8.

4. Weaver LK. Clinical practice. Carbon monoxide poisoning. N 
Engl J Med 2009;360(12):1217-25.

5. Da Silva JL, Lacombe C, Bruneval P, et al. Tumor cells are the site of erythropoietin synthesis in human renal cancers associated with polycythemia. Blood 1990;75(3):577-82.

6. Wiesener MS, Seyfarth M, Warnecke C, et al. Paraneoplastic erythrocytosis associated with an inactivating point mutation of the von Hippel-Lindau gene in a renal cell carcinoma. Blood 2002;99(10):3562-5.

7. James C, Ugo V, Le Couedic JP, et al. A unique clonal JAK2 mutation leading to constitutive signalling causes polycythaemia vera. Nature 2005;434(7037):1144-8.

8. Keohane C, McMullin MF, Harrison C. The diagnosis and management of erythrocytosis. BMJ 2013;347:f6667.

9. Manzanares W, Hardy G. Vitamin B12: The forgotten micronutrient for critical care. Curr Opin Clin Nutr Metab Care 2010;13(6):662-8.

10. Brady J, Wilson L, McGregor L, et al. Active B12: A rapid, automated assay for holotranscobalamin on the Abbott AxSYM analyzer. Clin Chem 2008;54(3):567-73.

11. Ermens AA, Vlasveld LT, Lindemans J. Significance of elevated cobalamin (vitamin B12) levels in blood. Clin Biochem 2003;36(8):585-90.

12. Carmel $R$, Tatsis $B$, Baril $L$. Circulating antibody to transcobalamin II causing retention of vitamin B12 in the blood. Blood 1977;49(6):987-1000.
13. Gimsing P. Cobalamin forms and analogues in plasma and myeloid cells during chronic myelogenous leukaemia related to clinical condition. Br J Haematol 1995;89(4):812-9.

14. Demircioğlu S, Yeler A, Doğan A. Evaluation of serum B12 level in patients with acute myeloid leukemia. LLM Dergi 2018;2(4):89-92.

15. Omer A, Finlayson ND, Shearman DJ, et al. Erythrocyte vitamin B12 activity in health, polycythemia, and in deficiency of vitamin B12 and folate. Blood 1970;35(1):73-82.

16. Rachmilewitz B, Manny N, Rachmilewitz M. The transcobalamins in polycythaemia vera. Scand $\mathrm{J}$ Haematol 1977;19(5):453-62.

17. Berlin NI. Diagnosis and classification of the polycythemias. Semin Hematol 1975;12(4):339-51.

18. McAloon EJ, Streiff RR, Kitchens CS. Erythrocytosis associated with carboxyhemoglobinemia in smokers. South Med J 1980;73(2):137-9.

19. Balcerzak SP, Bromberg PA. Secondary polycythemia. Semin Hematol 1975;12(4):353-82. 